\title{
Variant Inferior Root of Ansa Cervicalis
}

\author{
Variación de la Raíz Inferior del Asa Cervical
}

\author{
B. Prakash Babu
}

\begin{abstract}
BABU, P. B. Variant inferior root of ansa cervicalis. Int. J. Morphol., 29(1):240-243, 2011.
SUMMARY: Ansa cervicalis is a loop of nerves found in the anterior wall of the carotid sheath in the carotid triangle of neck innervating infrahyoid muscles. Its superior root has fibres from the first cervical nerve that leaves the hypoglossal nerve and joins the inferior root formed by the branches from the second and third cervical nerves. The two roots join to form ansa cervicalis. The ansa cervicalis nerve formation is relatively complex, as its course and location along the great vessels of the neck vary. In the present case on the left side of an adult male cadaver the inferior root was absent and the contributions from C2 and C3 were joining independently with the superior root of ansa to form ansa cervicalis. However no such variation was found in the ansa cervicalis formation on the right side.
\end{abstract}

KEY WORDS: Ansa cervicalis; Inferior root; Variation.

\section{INTRODUCTION}

Ansa cervicalis is a thin loop of nerves in the neck formed by ventral rami of upper three cervical nerves. It is formed by a superior and an inferior root at the front of the common carotid artery (Gray, 1876; Romanes, 1981). The superior root (descendens hypoglossi) arises from the hypoglossal nerve, although its fibres are derived from the first cervical nerve. $\mathrm{C} 1$ fibres also supply thyrohyoid and geniohyoid muscles via the hypoglossal nerve. Superior root gives a branch to the superior belly of the omohyoid, before it joins the inferior root.

The inferior root is formed from the fibres of the second and third cervical nerves (Romanes; Hamilton, 1956). It passes downwards on the lateral side of the internal jugular vein, crosses infront of this vein a little below the middle of the neck and joins the superior root infront of the common carotid artery (William \& Warwick, 1980). The two roots form a loop ansa cervicalis from which branches arise to supply the remaining infrahyoid (strap) muscles of the neck namely, sternohyoid, sternothyroid and inferior belly of omohyoid. Clasically twigs from ansa are occasionally reported to descend into the thorax and join cardiac and phrenic nerves (Gray; Larsell, 1953; Berry et al., 1995).

The ansa cervicalis formation is relatively complex, as its course and location along the great vessels of the neck may vary. In the past few years ansa cervcalis has been utilized to innervate the muscles of larynx paralyzed due to surgical procedures performed in the neck by nerve implantation or neuromuscular transfer (Tucker, 1979; Liang, 1993; Nasri et al., 1994). Ansa cervicalis is used for nerve anastamosis with the recurrent laryngeal nerve due to its proximity to the larynx, as a neuromuscular pedicle (Chhetri \& Berke 1997; Vollala et al., 2005; Rao et al., 2007). Good knowledge of topographical relationships of structures in the neck and their variations is one of the key prerequisites for successful surgery.

\section{CASE REPORT}

During dissection on the left side of the neck of adult male cadaver, a rare variation in the formation of ansa cervicalis, involving its inferior root was observed. The superior root of ansa cervicalis had its normal origin from the ventral ramus of $\mathrm{C} 1$ spinal nerve which joined the hypoglossal nerve and separated from it as superior root (descendens hypoglossi). The inferior root which is normally formed by the union of $\mathrm{C} 2$ and $\mathrm{C} 3$ fibres was absent. Branches from spinal nerves $\mathrm{C} 2-\mathrm{C} 3$ joined the superior root independently (Fig. 1). They were superficial to internal 
jugular vein before joining the superior root. From this formation of ansa, infrahyoid muscles received their innervations (Fig. 2). However no such variation was found in the ansa cervicalis formation on the right side.

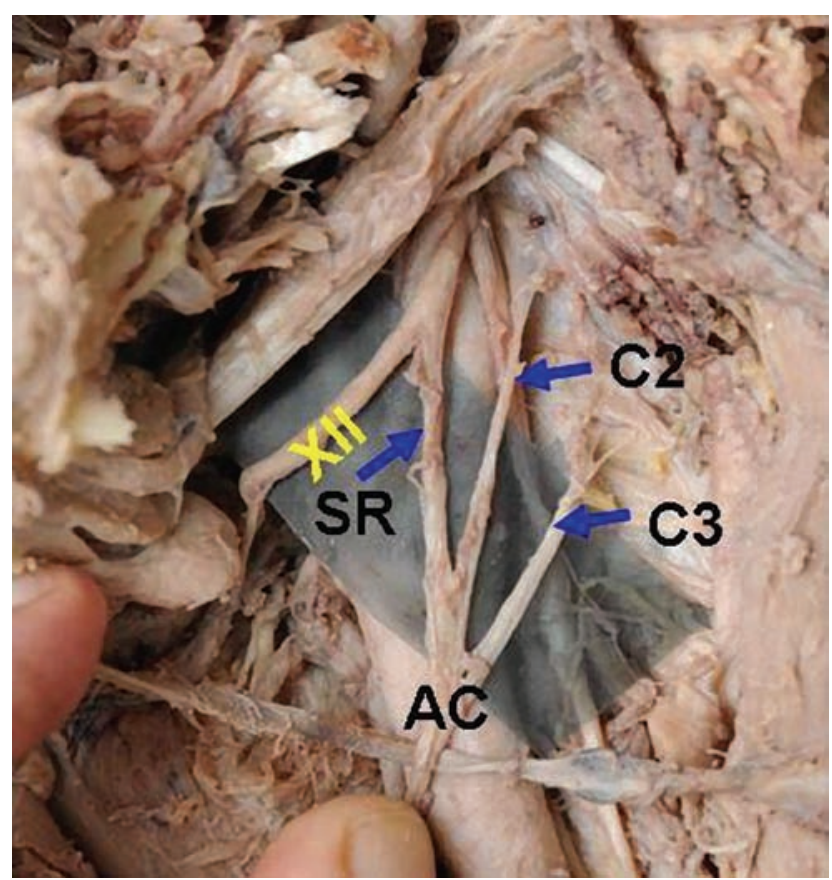

Fig.1. Detail of inferior root of ansa cervicalis. It is formed separately from ventral rami of spinal nerves $\mathrm{C} 2, \mathrm{C} 3$ (SR: superior root of ansa cervicalis, C2, C3 ventral rami of cervical spinal nerves', AC: Ansa cervicalis, XII: Hypoglossal nerve.
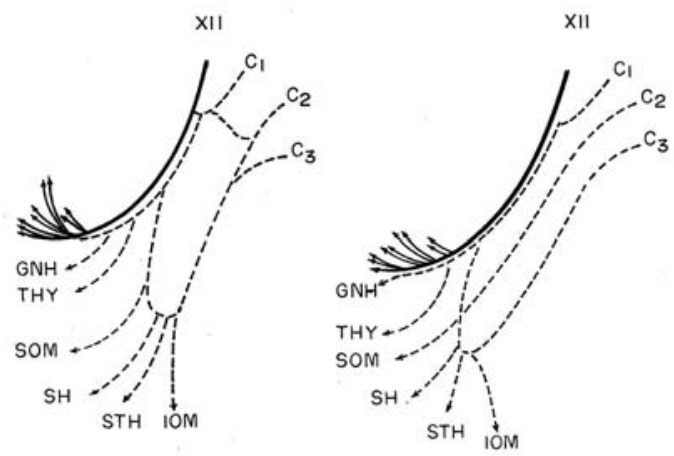

Fig. 2. A) Common arrangement of the ansa; B) arrangement of ansa in the present case. (XII: hypoglossal nerve; C1, C2, C3; fibres from ventral rami of the cervical spinal nerves; GNH: fibres to geniohyoid; THY: fibres to thyrohyoid; SOM: fibres to superior belly of omohyoid; SH: fibres to sternohyoid: STH: fibres to sternothyroid; IOM: fibres to inferior belly of omohyoid.

\section{DISCUSSION}

In this unusual case, the inferior root of ansa cervicalis was absent and branches from ventral rami of second and third cervical nerves were joining the superior root independently. This variation may be significant and of clinical importance.

The course and location of ansa cervicalis along the great vessels of neck widely varies among the individuals. Normally the descendens hypoglossi (Superior root of ansa) leaves the hypoglossal nerve where it curves round the occipital artery and then descends in the anterior wall of the carotid sheath. Before joining the descendens cervicalis (inferior root of ansa) it gives a branch to the superior belly of omohyoid. From the ansa cervicalis branches are given off to the sternohyoid, sternothyroid and inferior belly of omohyoid, another branch descends in to the thorax to join the cardiac and phrenic nerves (Williams et al., 1995).

The ansa cervicalis may arise from the first, second and third or only from the second and third cervical nerves. The descendens hypoglossi may be replaced by a branch from the vagus nerve. When the ansa cervicalis is absent, the infrahyoid muscles received their innervation directly from $\mathrm{C} 2$ and $\mathrm{C} 3$. The nerve to the thyrohyoid may arise as a branch of the ramus descendens hypoglossi. The phrenic nerve may also receive a contribution from the descendens hypoglossi (Bergman et al., 1988).

The ansa usually may be found between the sheaths of the sternocleidomastoid muscle and the common carotid artery, superficial to the internal jugular vein; sometimes it may lie in the carotid sheath between the carotid artery and the jugular vein; rarely may it lie dorsal to both the artery and vein. Rarely, the superior ramus may be associated with the vagus nerve instead with the hypoglossal nerve. In such cases it is called the descendens vagi instead of the descendens hypoglossi (Anson, 1966; Hollinshed, 1985).

The formation of inferior root (descendens cervicalis) varies considerably when compared to that of the superior root owing to the various cervical root contributions possible in its formation (Berry et al., 1995). The inferior root most commonly arises from the junction of $\mathrm{C} 2$ and $\mathrm{C} 3$, although it may receive contributions from $\mathrm{C} 1$ and $\mathrm{C} 4$ cervical spinal nerves. In a study conduction 160 stillborn infant cadavers (Poviraev \& Chernikov, 1967) the inferior root of ansa cervicalis was arising from ventral rami of $\mathrm{C} 2$ and $\mathrm{C} 3$ in $74 \%$ of the cases, from $\mathrm{C} 2, \mathrm{C} 3$ and $\mathrm{C} 4$ in 14\%, from $\mathrm{C} 3$ alone in 5\%, from $\mathrm{C} 2$ alone in $4 \%$ and from $\mathrm{C} 1, \mathrm{C} 2$ and $\mathrm{C} 3$ in $2 \%$. In series of Caliot and Dumont, $\mathrm{C} 3$ was the most frequent contributor to the inferior root, with 64 cases (80\%), and C2 contributed in 29 cases $(36 \%)$. Absence of inferior root has been reported 
with a frequency of 3\% (Chhetri \& Berke). There are other reports of unusual origin of inferior root of ansa from vagus nerve or sympathetic chain, which can be traced back into ventral rami of cervical nerves (Chhetri \& Berke). The origin of inferior root by two rootlets, one originating from spinal accessory nerve and other from a branch of the cervical nerves supplying sternomastoid has also been reported (Khakhi et al., 2006).

In general, contributing branches of the inferior root emerging from ventral rami $(\mathrm{C} 2, \mathrm{C} 3)$ of cervical nerves combine before they join the superior root to form ansa cervicalis. The joining of the fibers of inferior root can occur anywhere from $1.7 \mathrm{~cm}$ to $4.4 \mathrm{~cm}$ from the summit of the ansa (Caliot et al., 1986). Sometimes the contributing branches travel and the formation of the inferior root is completed over the internal jugular vein. This has been reported to occur at a frequency of $15 \%$ (Kunaik \& Klacansk $\ddagger$ 1982). The downward course of inferior root has two main patterns and both are related to the internal jugular vein (Warwick \& Williams, 1973).

The inferior root at first lies posterior and then lateral to internal jugular vein and then crosses infront of this vein a little below the middle of neck to join with the superior root infront of the vein. In other pattern, the root may pass medial to internal jugular vein, passing between this vein and common carotid artery (Warwick \& Williams). Both these patterns occur frequently. In a study of 118 dissections, the nerve was found to pass on the lateral side of the internal jugular vein in 57\% of the cases, and the medial side of the internal jugular vein in $43 \%$ of cases (Grant, 1962). In these cases, the formation of the ansa loop occurs between the internal jugular vein and common carotid artery and some dissection of carotid sheath is necessary to expose it. However, the dangers of an inadvertent injury to the great vessels are significant and it would be prudent to initially locate the individual nerve branches or to use a nerve stimulator to find the ansa over the carotid sheath. Inferior root was lateral in position in $81 \%$ of cases and medial in position in $15 \%$ of cases (Caliot et al.). Therefore, the superior and inferior roots of the ansa cervicalis most frequently meet over the lateral wall of the internal jugular vein.

Damage to the ansa can lead to change in voice quality after some time, even though the exact reason is not known for this phenomenon. It may be because of the loss of support provided by the strap muscles to the laryngeal cartilages during the movements of vocal folds (Vollala et al., 2005).

In the recent years, there has been a proliferation of techniques utilizing the ansa cervicalis nerve to reinnervate the paralyzed laryngeal muscles, such as nerve to nerve anastomosis with the recurrent laryngeal nerve. The ansa cervicalis is used in reinnervation of larynx because of its proximity to the larynx. The ansa cervicalis is also used in preventing the morbidity associated with tongue hemiatrophy after facial-hypoglossal anastomosis has been reported (Kukwa et al., 1994). Ansa cervicalis can be sacrificed without any serious functional disturbance, therefore it is an ideal candidate for use in nerve grafting in the neck. The formation of the lower root (descendens cervicalis) varies greatly when compared with that of the upper root owing to the possibility various cervical root possible in its formation (Berry et al., 1995).

Exact clinical significance of the present case cannot be postulated, as there is no available literature on such variation.

\section{ACKNOWLEDGMENTS}

Author thanks Professor and Head of the Department of Anatomy for giving permission to publish the paper and Dr. Ramachandra Bhat for his valuable suggestions.

BABU, P. B. Variante de la raíz inferior del asa cervical. Int. J. Morphol., 29(1):240-243, 2011.

RESUMEN: El asa cervical es un loop de nervios que se encuentra en la pared anterior de la vaina carotídea, en el triángulo carotídeo del cuello, que inerva los músculos infrahioideos. Su raíz superior tiene fibras del primer nervio cervical que sale del nervio hipogloso y se une a la raíz inferior formada por las ramas de los nervios cervicales segundo y tercero. Las dos raíces se unen para formar el asa cervical. La formación del asa cervical del nervio es relativamente compleja, ya que su curso y ubicación varía a lo largo de los grandes vasos del cuello. En el lado izquierdo del cuello de un cadáver adulto de sexo masculino, la raíz inferior del asa cervical estaba ausente y las contribuciones de los ramos de $\mathrm{C} 2$ y C3 se unieron, de forma independiente, con la raíz superior del asa y así formar el loop.

PALABRAS CLAVE: Asa cervical; Raíz inferior; Variación. 


\section{REFERENCES}

Anson, B. J. Morris' human anatomy. $12^{\text {th }}$ Ed. New York, Mc Graw-Hill, 1996. pp.1056-7.

Bergman, R. A.; Thompson, S. A.; Afifi, A. K. \& Sadeh, F. A. Compendium of human anatomic variations. Text, atlas and world literature. Baltimore-Munich: Urban and Schwarzenberg, 1988. p.137

Berry, M.; Bannister, L. H. \& Standring, S. M. Nervous system. In: Gray's Anatomy. Williams, P. L. (Ed). Edinburgh, Churchill Livingstone, 1995.

Caliot, P.; Dumont, D.; Bousquet, V. \& Midy, D. A note on the anastomoses between the hypoglossal nerve and the cervical plexus. Surg. Radiol. Anat., 8(1):75-9, 1986.

Chhetri, D. K. \& Berke, G. S. Ansa cervicalis nerve: review of the topographic anatomy and morphology. Laryngoscope, 107(10):1366-72, 1997.

Grant, J. B. An Atlas of Anatomy. $5^{\text {th }}$ Ed. Baltimore, Williams \& Wilkins, 1962.

Gray, H.C. Anatomy: Descriptive and Surgical. Philadelphia, H.C. Les, 1876.

Hamilton, W. J. Textbook of human anatomy. $1^{\text {st }}$ Ed. London, Macmilan, 1956. pp.869-70.

Hollinshead, W. H. \& Rosse, C. Textbook of Anatomy. $4^{\text {th }}$ Ed. New York, Harper and Row, 1985.

Khaki, A. A.; Shokouhi, G.; Shoja, M. M.; Farahani, R. M.; Zarrintan, S.; Khaki, A.; Montazam, H.; Tanoomand, A. \& Tubbs, R. S. Ansa cervicalis as a variant of spinal accessory nerve plexus: a case report. Clin. Anat., 19(6):540-3, 2006.

Kukwa, A.; Marchel, A.; Pietniczka, M.; Rakowicz, M. \& Krajewski, R. Reanimation of the face after facial nerve palsy resulting from resection of a cerebellopontine angle tumour. Br. J. Neurosurg., 8(3):327-32, 1994.

Kuniak, B. \& Klacansk $\ddagger$ J. Topographic anatomy of the ansa cervicalis with reference to reinnervation of the larynx. Cesk. Otolaryngol., 31(3):170-5, 1982.

Larsell, O. The nervous system. In: Morris' Human Anatomy. Schaeffer, J. P. (Ed). New York, Blackiston, 1953.
Liang, L. Reinnervation of posterior cricoarytenoid muscle: a comparison of nerve implantation and neuromuscular pedicle transfer in an animal model. Zhonghua $\mathrm{Er} \mathrm{Bi}$ Yan Hou Ke Za Zhi, 28(1):19-21, 59, 1993.

Nasri, S.; Sercarz, J. A.; Ye, M.; Kreiman, J.; Gerratt, B. R. \& Berke, G. S. Effects of arytenoid adduction on laryngeal function following ansa cervicalis nerve transfer for vocal fold paralysis in an in vivo canine model. Laryngoscope, 104(10):1187-93, 1994.

Poviraev, N. P. \& Chernikov, Y. F. Anatomy of the ansa cervicalis. Exerpta Medica, 21(1):219, 1967.

Rao, T. R.; Shetty, P. \& Rao, S. R. A rare case of formation of double ansa cervicalis: a case report. Neuroanatomy, 6:26-7, 2007.

Romanes, G. J. Cunningham's textbook of anatomy. $12^{\text {th }} \mathrm{Ed}$. London, Oxford University Press, 1981.

Tucker, H. M. Reinnervation of the paralyzed larynx: a review. Head Neck Surg., 1(3):235-42, 1979.

Vollala, V. R.; Bhat, S. M.; Nayak, S.; Raghunathan, D.; Samuel, V. P.; Rodrigues, V. \& Mathew, J. G. A rare origin of upper root of ansa cervicalis from vagus nerve: a case report. Neuroanatomy, 4:8-9, 2005.

Warwick, R. \& Williams, P. L. Gray's Anatomy. $35^{\text {th }}$ Ed. Philadelphia, WB Saunders, 1973. pp.1034-7.

Williams, P. L.; Bannister, L. H.; Berry, M. M.; Collins, P.; Dyson, M.; Dussek, J. E. \& Ferguson, M. W. J. Gray's Anatomy. $38^{\text {th }}$ Ed. Baltimore, Churchill Livingstone, 1995.

Williams, P. L. \& Warwick, R. Gray 's Anatomy. $36^{\text {th }}$ Ed. New York, Churchill Livingstone, 1980. pp.1091-4.

Correspondence to:

Dr. Prakash Babu.B

Associate Professor of Anatomy

Kasturba Medical College, Manipal

Karnataka-576104

INDIA

Phone: 91-820-2922327

Received: 29-06-2010

Accepted: 25-11-2010 